\title{
Tindak Pidana Pembakaran Hutan di Provinsi Riau Menurut Perspektif Hukum Islam*
}

\author{
Olivia Anggie Johar ${ }^{1}$ \\ Universitas Lancang Kuning, Indonesia \\ doi) https://doi.org/10.32507/mizan.v4i2.802
}

\begin{abstract}
This research aims to explain the crime of forest burning in Riau Province from the perspective of Islamic law. The method used in this research is socio-legal research. Forests are both a gift and a mandate from God which is bestowed on the Indonesian people as one of the most valuable natural resources. Based on Article 50 paragraph (3) letter d Law Number 41 of 1999 concerning Forestry, it is stated that everyone is prohibited from burning forests. In 2019 there were forest fires in Riau Province covering an area of 75,871 hectares. The implementation of Law Number 41 of 1999 concerning Forestry in Riau Province hasn't progressed as expected. Riau Provincial Government can take preventive measures to minimize the occurrence of forest fires by providing legal education to the community by cooperating with the police and religious figures who are popular in the community. Based on the Fatwa of the Council of Indonesian Ulama Number 30 of 2016 concerning the Law of Forest and Land Burning and Its Control, it is emphasized that carrying out forest burning which can cause damage, environmental pollution, loss of others, health problems, and other bad impacts is forbidden.
\end{abstract} Keywords: Forest; Criminal Act; Islamic Law

\begin{abstract}
Abstrak
Penelitian ini bertujuan untuk menjelaskan tindak pidana pembakaran hutan di Provinsi Riau menurut perspektif hukum Islam. Metode yang digunakan dalam penelitian ini adalah penelitian hukum sosiologis. Hutan merupakan karunia sekaligus amanah dari Allah yang dianugerahkan kepada bangsa Indonesia sebagai salah satu kekayaan alam yang sangat berharga. Berdasarkan Pasal 50 ayat (3) huruf d Undang-Undang Nomor 41 Tahun 1999 tentang Kehutanan ditegaskan bahwa setiap orang dilarang membakar hutan. Pada tahun 2019 telah terjadi kebakaran hutan di Provinsi Riau seluas 75.871 Ha. Implementasi UndangUndang Nomor 41 Tahun 1999 tentang Kehutanan di Provinsi Riau belum berjalan sebagaimana yang diharapkan. Pemerintah Provinsi Riau dapat melakukan upaya pencegahan untuk meminimalisir terjadinya kebakaran hutan dengan memberikan penyuluhan hukum kepada masyarakat dengan menggandeng pihak kepolisian maupun tokoh-tokoh agama yang populer di tengah-tengah masyarakat. Berdasarkan Fatwa Majelis Ulama Indonesia Nomor 30 Tahun 2016 tentang Hukum Pembakaran Hutan dan Lahan serta Pengendaliannya ditegaskan bahwa melakukan pembakaran hutan yang dapat menimbulkan kerusakan, pencemaran lingkungan, kerugian orang lain, gangguan kesehatan, dan dampak buruk lainnya hukumnya adalah haram.
\end{abstract}

Kata kunci: Hutan; Tindak Pidana; Hukum Islam

${ }^{*}$ Naskah diterima tanggal: 17 September 2020, direvisi: 27 Oktober 2020, disetujui untuk terbit: 10 Desember 2020.

${ }^{1}$ Olivia Anggie Johar adalah dosen tetap bidang hukum pidana Fakultas Hukum, Universitas Lancang Kuning, Riau. e-Mail: oliviaanggiejohar@unilak.ac.id 


\section{A. PENDAHULUAN}

Hutan merupakan karunia sekaligus amanah dari Allah yang dianugerahkan kepada bangsa Indonesia sebagai salah satu kekayaan alam yang sangat berharga. Dalam Kamus Besar Bahasa Indonesia (KBBI) dijelaskan bahwa definisi hutan adalah tanah luas yang ditumbuhi oleh pohon-pohon dan biasanya tidak dipelihara oleh orang. Sejalan dengan itu, Undang-Undang Nomor 41 Tahun 1999 tentang Kehutanan mendefinisikan hutan adalah suatu kesatuan ekosistem berupa hamparan lahan yang luas yang berisi sumber daya alam hayati yang didominasi oleh pepohonan yang tidak dapat dipisahkan antara yang satu dengan yang lainnya.

Hutan merupakan unsur utama sistem penyangga kehidupan manusia dan merupakan modal dasar bagi pembangunan nasional serta memiliki manfaat yang nyata, baik manfaat ekologi, manfaat sosial dan budaya, maupun manfaat ekonomi. Oleh karena itu, pengelolaan hutan harus dilakukan secara terencana dan bertanggung jawab sesuai dengan kebutuhan serta memperhatikan kelestarian hutan dan keseimbangan lingkungan hidup dalam rangka mendukung program pembangunan kehutanan yang berkelanjutan bagi kesejahteraan rakyat sebagaimana yang diatur dalam Undang-Undang Dasar Negara Republik Indonesia Tahun 1945. 2 Pasal 33 ayat (3) Undang-Undang Dasar Negara Republik Indonesia Tahun 1945 mengamanatkan bahwa bumi, air, dan kekayaan alam yang terkandung di dalamnya dikuasai oleh negara dan dipergunakan untuk sebesar-besarnya kemakmuran rakyat.

Dalam rangka optimalisasi manfaat hutan untuk meningkatkan kesejahteraan masyarakat, maka pada prinsipnya semua hutan dapat dimanfaatkan, dengan pengecualian bahwa tidak diizinkan mengubah fungsi pokok hutan, yaitu fungsi konservasi, fungsi lindung, dan fungsi produksi. ${ }^{3}$ Berdasarkan Pasal 6 Undang-Undang Nomor 41 Tahun 1999 tentang Kehutanan disebutkan bahwa hutan mempunyai tiga fungsi, yaitu fungsi konservasi, fungsi lindung, dan fungsi produksi. Oleh karena itu, pemerintah kemudian menetapkan tiga jenis hutan berdasarkan fungsinya tersebut, yaitu hutan konservasi, hutan lindung, dan hutan produksi.

Penguasaan hutan dan sumber daya alam yang ada di dalamnya oleh negara memberikan kewenangan kepada pemerintah sebagai penyelenggara negara untuk mengatur dan mengurus segala sesuatu yang berkaitan dengan hutan, kawasan hutan, dan hasil hutan. Pemerintah juga berwenang menetapkan kawasan hutan dan/atau mengubah status kawasan hutan. Selain itu, pemerintah juga berwenang mengatur dan menetapkan hubungan hukum antara orang dan hutan atau kawasan hutan dan hasil hutan. Terakhir, pemerintah juga diberikan kewenangan untuk mengatur perbuatan hukum mengenai kehutanan. ${ }^{4}$

Penguasaan hutan oleh negara bukan merupakan pemilikan, tetapi negara memberikan kewenangan kepada pemerintah untuk mengatur dan mengurus segala

2 Salim HS., Dasar-dasar Hukum Kehutanan, (Jakarta: Sinar Grafika, 2013), h. 7.

3 Supriadi, Hukum Kehutanan dan Hukum Perkebunan di Indonesia, (Jakarta: Sinar Grafika, 2010), h. 28.

${ }^{4}$ Abdul Muis Yusuf dan Mohammad Taufik Makarao, Hukum Kehutanan di Indonesia, (Jakarta: Rineka Cipta, 2011), h. 12. 
sesuatu yang berkaitan dengan hutan, kawasan hutan, dan hasil hutan. Pemerintah berwenang untuk memberikan izin kepada pihak lain untuk mengelola hutan. Pengelolaan hutan dilakukan dengan pemberian izin pemanfaatan kawasan, izin pemanfaatan jasa lingkungan, izin pemanfaatan hasil hutan kayu dan izin pemanfaatan hasil hutan bukan kayu, serta izin pemungutan hasil hutan kayu dan bukan kayu.

Hutan merupakan kekayaan alam bangsa Indonesia yang harus dijaga kelestariannya. Oleh karena itu, berdasarkan Pasal 50 ayat (3) Huruf d Undang-Undang Nomor 41 Tahun 1999 tentang Kehutanan ditegaskan bahwa setiap orang dilarang membakar hutan. Larangan membakar hutan tersebut secara filosofis merujuk dari firman Allah dalam Al-Qur'an surat Al-Baqarah ayat 60 yang berbunyi: "Makan dan minumlah dari rezeki (yang diberikan) Allah dan janganlah kamu berkeliaran di bumi dengan membuat kerusakan".

Kebakaran hutan bukanlah fenomena yang langka yang terjadi di Indonesia, khususnya di Provinsi Riau. Kebakaran hutan di Provinsi Riau rutin terjadi setiap tahunnya. Hutan yang terbakar kemudian mengakibatkan polusi udara berupa kabut asap yang dapat merusak kesehatan, bahkan kabut asap tersebut menyebar hingga ke negara-negara tetangga seperti Malaysia dan Singapura. Peneliti memperoleh data dari website Badan Nasional Penanggulangan Bencana (BNPB) Republik Indonesia bahwa pada tahun 2019 telah terjadi kebakaran hutan di Provinsi Riau seluas 75.871 Ha.

Dari latar belakang permasalahan yang telah diuraikan di atas, maka penelitian ini bertujuan untuk menjelaskan tindak pidana pembakaran hutan di Provinsi Riau menurut perspektif hukum Islam.

\section{B. METODE PENELITIAN}

Penelitian hukum adalah suatu kegiatan ilmiah yang didasarkan pada metode, sistematika, dan pemikiran tertentu yang bertujuan untuk mempelajari satu atau beberapa gejala hukum tertentu dengan jalan menganalisanya. ${ }^{5}$ Metode yang digunakan dalam penelitian ini adalah penelitian hukum sosiologis. Penelitian hukum sosiologis adalah suatu penelitian yang dilakukan dengan cara menganalisa pelaksanaan peraturan perundang-undangan terhadap permasalahan yang terjadi di tengah-tengah masyarakat. ${ }^{6}$ Sumber data yang digunakan dalam penelitian ini adalah data primer dan data sekunder. Data primer yaitu data yang diperoleh langsung dari hasil observasi dan wawancara di lokasi penelitian; sedangkan data sekunder yaitu data yang diperoleh dari jurnal-jurnal ilmiah, literatur hukum, dan peraturan perundang-undangan. Teknik pengumpulan data yang digunakan dalam penelitian ini adalah observasi, wawancara, dan studi kepustakaan. Teknik analisis data yang digunakan dalam penelitian ini adalah analisis kualitatif.

\footnotetext{
${ }^{5}$ Soerjono Soekanto, Pengantar Penelitian Hukum, (Jakarta: UI Press, 2007), h. 43.

${ }^{6}$ Zainuddin Ali, Metode Penelitian Hukum, (Jakarta: Sinar Grafika, 2013), h. 25.
} 


\section{ANALISIS DAN PEMBAHASAN}

\section{Prinsip Dasar Penyelenggaraan Kehutanan}

Dasar hukum yang mengatur mengenai hutan di Indonesia adalah UndangUndang Nomor 41 Tahun 1999 tentang Kehutanan. Asas-asas dalam penyelenggaraan kehutanan di Indonesia yaitu sebagai berikut; Pertama, Asas Manfaat dan Lestari. Penyelenggaraan kehutanan berasaskan manfaat dan lestari dimaksudkan agar setiap pelaksanaan penyelenggaraan kehutanan memperhatikan keseimbangan dan kelestarian unsur lingkungan, unsur sosial, unsur budaya, dan unsur ekonomi.

Kedua, Asas Kerakyatan dan Keadilan. Penyelenggaraan kehutanan berasaskan kerakyatan dan keadilan dimaksudkan agar setiap penyelenggaraan kehutanan harus memberikan peluang dan kesempatan yang sama kepada semua warga negara sesuai dengan kemampuannya sehingga dapat meningkatkan kemakmuran seluruh rakyat.

Ketiga, Asas Kebersamaan. Penyelenggaraan kehutanan berasaskan kebersamaan dimaksudkan agar dalam penyelenggaraan kehutanan menerapkan pola usaha bersama, sehingga terjalin saling keterkaitan dan saling ketergantungan secara sinergis antara masyarakat setempat dengan Badan Usaha Milik Negara (BUMN) atau Badan Usaha Milik Daerah (BUMD) dan perusahaan swasta di Indonesia dalam rangka pemberdayaan koperasi dan Usaha Mikro, Kecil, dan Menengah (UMKM).

Keempat. Asas Keterbukaan. Penyelenggaraan kehutanan berasaskan keterbukaan dimaksudkan agar setiap kegiatan penyelenggaraan kehutanan mengikutsertakan masyarakat dan memperhatikan aspirasi masyarakat. Kelima, Asas Keterpaduan. Penyelenggaraan kehutanan berasaskan keterpaduan dimaksudkan agar setiap penyelenggaraan kehutanan dilakukan secara terpadu dengan memperhatikan kepentingan nasional, kepentingan sektor lain, dan kepentingan masyarakat setempat.

Sebagai karunia sekaligus amanah dari Allah yang sangat berharga yang dianugerahkan kepada bangsa Indonesia, hutan dapat dimanfaatkan oleh rakyat Indonesia untuk menopang kehidupannya sehari-hari. Oleh karena itu, hutan harus dijaga kelestariannya agar dapat diwariskan secara turun-temurun dari generasi ke generasi. Sejalan dengan itu, pada Pasal 50 ayat (3) huruf d Undang-Undang Nomor 41 Tahun 1999 tentang Kehutanan ditegaskan bahwa setiap orang dilarang membakar hutan. Ketentuan tersebut dapat diartikan bahwa meskipun hutan dapat dimanfaatkan dalam kehidupan sehari-hari, namun setiap orang dilarang membakar hutan untuk memperoleh manfaatnya agar kelestarian hutan tetap terjaga. ${ }^{7}$

Faktanya, kebakaran hutan rutin terjadi di Indonesia. Kebakaran hutan bukanlah fenomena yang langka di Indonesia, khususnya di Provinsi Riau. Kebakaran hutan di Provinsi Riau rutin terjadi setiap tahun. Hutan yang terbakar kemudian mengakibatkan polusi udara berupa kabut asap yang dapat merusak kesehatan, bahkan kabut asap tersebut menyebar hingga ke negara-negara tetangga seperti Malaysia dan Singapura. Peneliti memperoleh data dari website Badan Nasional Penanggulangan Bencana

\footnotetext{
${ }^{7}$ Andrew Shandy Utama dan Rizana, "Penegakan Hukum terhadap Kebakaran Hutan dan Lahan di Kabupaten Indragiri Hilir Provinsi Riau", dalam Jurnal The Juris, Vol. IV, No. 1 (2020), h. 35.
} 
(BNPB) Republik Indonesia bahwa pada tahun 2019 telah terjadi kebakaran hutan di Provinsi Riau seluas $75.871 \mathrm{Ha}$.

\section{Implementasi Undang-Undang Nomor 41 Tahun 1999 dan Hambatannya}

Implementasi Undang-Undang Nomor 41 Tahun 1999 tentang Kehutanan di Provinsi Riau belum berjalan sebagaimana yang diharapkan. Hal ini dikarenakan pada tahun 2019 masih terjadi kebakaran hutan seluas 75.871 Ha. Bahkan kebakaran hutan rutin terjadi setiap tahun. Perbuatan membakar hutan dapat dikategorikan sebagai tindak pidana menurut Undang-Undang Nomor 41 Tahun 1999 tentang Kehutanan.

Meskipun setiap orang secara tegas dilarang membakar hutan, peraturan perundang-undangan di Indonesia sebenarnya ada mengecualikan bahwa perbuatan membakar lahan dibolehkan dengan mempertimbangkan kearifan lokal. Berdasarkan Pasal 69 ayat (2) Undang-Undang Nomor 32 Tahun 2009 tentang Perlindungan dan Pengelolaan Lingkungan Hidup diatur bahwa ketentuan yang menegaskan setiap orang dilarang melakukan pembukaan lahan dengan cara membakar wajib memperhatikan dengan sungguh-sungguh kearifan lokal di daerah masing-masing. ${ }^{8}$ Ketentuan ini hadir karena di beberapa daerah masih ada tradisi masyarakat lokal dalam membuka lahan pertanian dan perkebunan dilakukan dengan cara membakar lahan.

Kapabilitas Pemerintah Provinsi Riau dalam mengendalikan kebakaran hutan belum berjalan dengan efektif karena hanya diarahkan pada proses pemadaman terhadap hutan yang terbakar dalam rangka mencegah kabut asap. Pemerintah sampai saat ini belum menemukan solusi yang ideal untuk mencegah kebakaran hutan yang rutin terjadi setiap tahun di Provinsi Riau. Selain itu, alokasi anggaran dana yang disediakan untuk penanganan kebakaran hutan masih terbatas jumlahnya sehingga Pemerintah Provinsi Riau harus menunggu bantuan dana dan peralatan teknis dari pemerintah pusat. Dengan hamparan hutan gambut yang luas, Pemerintah Provinsi Riau seharusnya mengalokasikan anggaran dana yang besar dalam rangka mengantisipasi terjadinya kebakaran hutan yang biasa terjadi pada musim kemarau. ${ }^{9}$

Hambatan dalam implementasi Undang-Undang Nomor 41 Tahun 1999 tentang Kehutanan di Provinsi Riau adalah masih minimnya pemahaman masyarakat mengenai manfaat hutan untuk jangka panjang. Sebagian besar masyarakat masih beranggapan bahwa hutan merupakan salah satu kekayaan sumber daya alam yang dapat dikelola sebagai mata pencariannya, tanpa mempertimbangkan bahwa hutan merupakan paruparu dunia sebagai penghasil udara segar yang baik untuk kesehatan manusia dan berguna untuk menyeimbangkan keadaan iklim global, sehingga hutan harus dijaga kelestariannya dan diwariskan untuk generasi yang akan datang.

${ }^{8}$ Hendra Eriant Dikser, “Analisis Yuridis terhadap Pengecualian Pembakaran Lahan dan Hutan Berdasarkan Pasal 69 Ayat (2) Undang-Undang Nomor 32 Tahun 2009 tentang Perlindungan dan Pengelolaan Lingkungan Hidup", dalam JOM Fakultas Hukum Universitas Riau, Vol. IV, No. 2 (2017), h. 15.

${ }_{9}$ Geovani Meiwanda, “Kapabilitas Pemerintah Daerah Provinsi Riau; Hambatan dan Tantangan Pengendalian Kebakaran Hutan dan Lahan”, dalam Jurnal Sosial Politik, Vol. 19, No. 3 (2016), h. 10. 
Hambatan lainnya dalam implementasi Undang-Undang Nomor 41 Tahun 1999 tentang Kehutanan di Provinsi Riau adalah masih lemahnya penegakan hukum terhadap tindak pidana pembakaran hutan. Hal ini dikarenakan meskipun telah lebih dari 20 (dua puluh) tahun Undang-Undang Nomor 41 Tahun 1999 tentang Kehutanan lahir sebagai dasar hukum yang melarang setiap orang untuk membakar hutan, tetapi kebakaran hutan masih rutin terjadi setiap tahunnya di Provinsi Riau.

Membakar hutan merupakan tindak pidana, sehingga dalam Undang-Undang Republik Indonesia Nomor 41 Tahun 1999 tentang Kehutanan diatur mengenai sanksi pidana yang tegas bagi siapa saja yang melakukan tindak pidana pembakaran hutan. Berdasarkan pada Pasal 78 ayat (3) Undang-Undang Nomor 41 Tahun 1999 tentang Kehutanan ditegaskan bahwa siapapun yang dengan sengaja membakar hutan dapat dipidana dengan pidana penjara paling lama 15 (lima belas) tahun dan pidana denda paling banyak Rp5.000.000.000,- (lima miliar rupiah). Berdasarkan Pasal 78 ayat (4) Undang-Undang Nomor 41 Tahun 1999 tentang Kehutanan juga ditegaskan bahwa siapapun yang karena kelalaiannya menyebabkan hutan terbakar dapat dipidana dengan pidana penjara paling lama 5 (lima) tahun dan pidana denda paling banyak Rp1.500.000.000,- (satu miliar lima ratus juta rupiah).

Selain itu, apabila tindak pidana pembakaran hutan dilakukan oleh badan hukum atau badan usaha dan/atau atas nama badan hukum atau badan usaha, maka tuntutan pidananya akan dijatuhkan kepada pengurus badan hukum atau badan usaha tersebut dengan pidana penjara paling lama 15 (lima belas) tahun dan pidana denda paling banyak Rp5.000.000.000,- (lima miliar rupiah), lalu ditambah dengan 1/3 (satu pertiga) dari sanksi pidana tersebut. ${ }^{10}$

\section{Penegakan Hukum Pidana Pembakaran Hutan di Propinsi Riau}

Tindak pidana pembakaran hutan yang dilakukan oleh perusahaan dan/atau atas nama perusahaan di Provinsi Riau pada tahun 2019 dapat diusut oleh pihak yang berwajib dengan menerapkan prinsip strict liability, yaitu pertanggungjawaban mutlak dari pelaku tindak pidana atas kejahatan yang telah dilakukannya. Prinsip strict liability pernah diterapkan dalam kasus tindak pidana pembakaran hutan di Provinsi Riau yang dilakukan oleh PT Adei Plantation pada tahun 2014.11

Dalam rangka mewujudkan efektivitas implementasi Undang-Undang Nomor 41 Tahun 1999 tentang Kehutanan di Provinsi Riau, dibutuhkan adanya penegakan hukum yang tegas dari pihak kepolisian terhadap siapa saja yang terbukti melakukan tindak pidana pembakaran hutan. Namun, penegakan hukum tidak selalu berjalan sebagaimana yang dicita-citakan dalam undang-undang. Dalam pelaksanaannya, terdapat faktor-faktor yang mempengaruhi proses penegakan hukum. Faktor-faktor

10 Wartiningsih, Pidana Kehutanan; Keterlibatan dan Pertanggungjawaban Penyelenggara Kebijakan Kehutanan, (Malang: Setara Press, 2014), h. 63.

11 Eko Ardiansyah Pandiangan, "Penerapan Prinsip Strict Liability dalam Pertanggungjawaban Korporasi yang Dianggap Bertanggung Jawab atas Kebakaran Hutan di Provinsi Riau", dalam JOM Fakultas Hukum Universitas Riau, Vol. III, No. 2 (2016), h. 15. 
yang mempengaruhi penegakan hukum yaitu faktor hukum itu sendiri (undangundang), faktor penegak hukum, faktor sarana yang mendukung penegakan hukum, faktor masyarakat, dan faktor kebudayaan. Kelima faktor tersebut saling berkaitan erat karena merupakan esensi dari penegakan hukum dan tolak ukur dari efektivitas penegakan hukum. ${ }^{12}$

Adapun kebijakan Dinas Kehutanan Provinsi Riau dalam menjaga kelestarian hutan di Provinsi Riau yaitu; a) memantapkan kawasan hutan sesuai dengan fungsinya, b) meningkatkan rehabilitasi hutan serta perhutanan sosial, c) mengoptimalkan perlindungan dan konservasi hutan, d) mengoptimalkan pemanfaatan hutan yang berwawasan lingkungan, e) menguatkan kelembagaan dan kewirausahaan masyarakat sekitar hutan, f) meningkatkan peran swasta kehutanan dalam pembangunan.

Pemerintah Provinsi Riau dapat melakukan upaya pencegahan untuk meminimalisir terjadinya kebakaran hutan. Salah satu bentuk upaya pencegahan yang dapat dilakukan oleh Pemerintah Provinsi Riau untuk meminimalisir terjadinya kebakaran hutan adalah dengan memberikan penyuluhan hukum kepada masyarakat mengenai larangan membakar hutan sebagaimana yang diatur dalam Undang-Undang Nomor 41 Tahun 1999 tentang Kehutanan, sanksi pidana bagi pelaku tindak pidana pembakaran hutan, serta bahaya kebakaran hutan bagi kehidupan manusia.

Agar penyuluhan hukum tersebut lebih efektif, Pemerintah Provinsi Riau dapat menjalin kerja sama dengan pihak kepolisian. Penguatan peran pihak kepolisian secara psikologis dapat meyakinkan masyarakat bahwa membakar hutan merupakan tindak pidana sebagaimana yang diatur dalam Undang-Undang Nomor 41 Tahun 1999 tentang Kehutanan. ${ }^{13}$ Pemerintah Provinsi Riau juga dapat menjalin kerja sama dengan tokohtokoh agama yang populer di tengah-tengah masyarakat untuk menyampaikan Fatwa Majelis Ulama Indonesia Nomor 30 Tahun 2016 tentang Hukum Pembakaran Hutan dan Lahan serta Pengendaliannya.

Berdasarkan Fatwa Majelis Ulama Indonesia (MUI) Nomor 30 Tahun 2016 tentang Hukum Pembakaran Hutan dan Lahan serta Pengendaliannya ditegaskan bahwa melakukan pembakaran hutan yang dapat menimbulkan kerusakan, pencemaran lingkungan, kerugian orang lain, gangguan kesehatan, dan dampak buruk lainnya hukumnya adalah haram.

Pemanfaatan hutan menurut perspektif hukum Islam pada prinsipnya boleh dilakukan dengan beberapa ketentuan yaitu; a) memperoleh hak yang sah dalam pemanfaatan hutan, b) Mendapatkan izin untuk memanfaatkan hutan dari pihak yang berwenang, c) Pemanfaatan hutan ditujukan untuk kemaslahatan umat, d) pemanfaatan hutan tidak menimbulkan kerusakan bagi lingkungan hidup.

Upaya pencegahan lainnya yang dapat dilakukan oleh Pemerintah Provinsi Riau untuk meminimalisir terjadinya kebakaran hutan adalah dengan meningkatkan peran

12 Soerjono Seokanto, Faktor-faktor yang Mempengaruhi Penegakan Hukum, (Jakarta: Rajawali Pers, 2013), h. 8-9.

${ }_{13}$ Andrew Shandy Utama, "Kepercayaan Masyarakat terhadap Penegakan Hukum di Indonesia", dalam Jurnal Ensiklopedia Social Review, Vol. 1, No. 3 (2019), h. 313. 
masyarakat dalam menjaga kelestarian hutan yang ada di sekitarnya. Berdasarkan Undang-Undang Nomor 41 Tahun 1999 tentang Kehutanan disebutkan bahwa masyarakat berkewajiban untuk ikut memelihara dan menjaga hutan dari gangguan dan perusakan yang dilakukan oleh orang-orang yang tidak bertanggung jawab. Salah satu bentuk peningkatan peran masyarakat untuk menjaga kelestarian hutan adalah dengan adanya penghargaan dari Pemerintah Provinsi Riau kepada masyarakat, baik perorangan maupun kelompok masyarakat, apabila mengetahui dan melaporkan pelaku pembakaran hutan.

\section{KESIMPULAN}

Berdasarkan Pasal 50 ayat (3) huruf d Undang-Undang Nomor 41 Tahun 1999 tentang Kehutanan ditegaskan bahwa setiap orang dilarang membakar hutan. Pada tahun 2019 telah terjadi kebakaran hutan di Provinsi Riau seluas 75.871 Ha. Implementasi Undang-Undang Nomor 41 Tahun 1999 tentang Kehutanan di Provinsi Riau belum berjalan sebagaimana yang diharapkan. Pemerintah Provinsi Riau dapat melakukan upaya pencegahan untuk meminimalisir terjadinya kebakaran hutan dengan memberikan penyuluhan hukum kepada masyarakat dengan menggandeng pihak kepolisian maupun tokoh-tokoh agama yang populer di tengah-tengah masyarakat.

Berdasarkan Fatwa Majelis Ulama Indonesia Nomor 30 Tahun 2016 tentang Hukum Pembakaran Hutan dan Lahan serta Pengendaliannya ditegaskan bahwa melakukan pembakaran hutan yang dapat menimbulkan kerusakan, pencemaran lingkungan, kerugian orang lain, gangguan kesehatan, dan dampak buruk lainnya hukumnya adalah haram.

\section{REFERENSI}

Ali, Zainuddin, Metode Penelitian Hukum, Jakarta: Sinar Grafika, 2013.

Dikser, Hendra Eriant, “Analisis Yuridis terhadap Pengecualian Pembakaran Lahan dan Hutan Berdasarkan Pasal 69 Ayat (2) Undang-Undang Nomor 32 Tahun 2009 tentang Perlindungan dan Pengelolaan Lingkungan Hidup", dalam JOM Fakultas Hukum Universitas Riau, Vol. IV, No. 2 (2017).

HS., Salim, Dasar-dasar Hukum Kehutanan, Jakarta: Sinar Grafika, 2013.

Meiwanda, Geovani, “Kapabilitas Pemerintah Daerah Provinsi Riau; Hambatan dan Tantangan Pengendalian Kebakaran Hutan dan Lahan", dalam Jurnal Sosial Politik, Vol. 19, No. 3 (2016).

Mukri, S.G.; Aji, A.M.; Yunus, N.R. (2016). "Implementation of Religious Education in the Constitution of the Republic of Indonesia," Salam: Sosial dan Budaya Syar-i, Volume 3 No. 3. 
Mukri, S.G.; Aji, A.M.; Yunus, N.R. (2017). Relation of Religion, Economy, and Constitution In The Structure of State Life, STAATSRECHT: Indonesian Constitutional Law Journal, Volume 1, No. 1.

Pandiangan, Eko Ardiansyah, "Penerapan Prinsip Strict Liability dalam Pertanggungjawaban Korporasi yang Dianggap Bertanggung Jawab atas Kebakaran Hutan di Provinsi Riau", dalam JOM Fakultas Hukum Universitas Riau, Vol. III, No. 2 (2016).

Soekanto, Soerjono, Faktor-faktor yang Mempengaruhi Penegakan Hukum, Jakarta: Rajawali Pers, 2013.

Soekanto, Soerjono, Pengantar Penelitian Hukum, Jakarta: UI Press, 2007.

Supriadi, Hukum Kehutanan dan Hukum Perkebunan di Indonesia, Jakarta: Sinar Grafika, 2010.

Utama, Andrew Shandy, "Kepercayaan Masyarakat terhadap Penegakan Hukum di Indonesia", dalam Jurnal Ensiklopedia Social Review, Vol. 1, No. 3 (2019).

Utama, Andrew Shandy, dan Rizana, “Penegakan Hukum terhadap Kebakaran Hutan dan Lahan di Kabupaten Indragiri Hilir Provinsi Riau", dalam Jurnal The Juris, Vol. IV, No. 1 (2020).

Wartiningsih, Pidana Kehutanan; Keterlibatan dan Pertanggungjawaban Penyelenggara Kebijakan Kehutanan, Malang: Setara Press, 2014.

Yunus, N.R.; Anggraeni, RR Dewi.; Rezki, Annissa. (2019). "The Application of Legal Policy Theory and its relationship with Rechtsidee Theory to realize Welfare State," 'Adalah, Volume 3, No. 1.

Yusuf, Abdul Muis, dan Mohammad Taufik Makarao, Hukum Kehutanan di Indonesia, Jakarta: Rineka Cipta, 2011. 
Olivia Anggie Johar 